\title{
PERCEIVED IMPACT OF SUBSTANCE ABUSE ON STUDENTS' ACADEMIC ACTIVITIES AMONG SENIOR SECONDARY SCHOOL STUDENTS IN JALINGO EDUCATION ZONE, TARABA STATE, NIGERIA: IMPLICATIONS FOR COUNSELLING
}

\author{
Menchak, Clifford Yubsih \\ Department of Guidance and Counselling, Taraba State University Jalingo- Nigeria \\ cliffordmenchak1@gmail.com \\ $+2348036363355$
}

\begin{abstract}
This study investigated the Perceived Impact of Substance Abuse on Students' Academic Activities among Senior Secondary School Students in Jalingo Education Zone of Taraba State, Nigeria. Descriptive survey research design was used for the study. One research question and one hypothesis were used to guide the study. A target population of four thousand, five hundred and ninety-four (4,594) Senior Secondary Students II from 47 secondary schools and a sample of three hundred and sixty eight (368) students were used for the study. Purposeful random sampling was used to select the respondents. Research instrument titled; Perceived Impact of Substance Abuse on Students' Academic Activities Questionnaire tagged [PISASAAQ] with reliability index of 0.705 was used to collect data. Descriptive statistics of mean and standard deviation and also inferential statistics of chisquare $\left(X^{2}\right)$ were used. Result revealed that Substance Abuse has significant impact on Academic Activities among Senior Secondary School Students in Jalingo Education Zone of Taraba State, Nigeria. The study recommends for comprehensive educational and legislative policies along with guidance programmes in all secondary schools in Taraba state and qualified Counsellors be made available in all Schools.
\end{abstract}

Keywords: Perceived Impact, Substance Abuse, Academic Activities. 


\section{Introduction}

The Nigerian National Drug Law Enforcement Agency (NDLEA) has stated that substance abuse is a major problem in schools, colleges and universities in Nigeria (NDLEA, 2013).

Substance abuse adversely affects academic performance, ability to build or maintain a satisfactory interpersonal relationship with peers, pervasive mood of unhappiness and fears associated with personal or poor academic performance. Students' academic activities is affected by numerous factor including gender, age, teaching faculty, students schooling, father/guardian social economic status, what they consume, students residential environment, medium of instructions in schools, tuition trend, daily study hour and accommodation as hostelries or day a student (Idoko, Muyiwa, Agoha \& Benedict, 2015).

Owen (2001), says, substance abuse can lead students into truancy and absenteeism and opined that in most cases student that absent from school, his or her Intelligent Quotient (IQ) would be retarded; and such students would score below average in his class work because he missed all the normal school lessons and all the academic activities which he is supposed to have acquired. Such a student would also associate with bad group which will influence his activities. Anything they do he will also do without having any second thought over it and this will eventually lure him/her into criminal deeds such as stealing, smoking, cultism and substance abuse. All these will increase his confidence in his bad behaviour which eventually have negative impact on his academic activities. Omoruyi (2014) attributed single-parenting based on parental socioeconomic status to have great influence of substance abuse on students' academic activities. Similarly, Coleman (2010) settles that drug abuse and addiction is detrimental to the socio-economic and intellectual advancement of a nation. Drug use by students has hampered education and management of secondary schools in Nigeria. It further emphasized that adolescent drug abuse is closely associated with other problems of behaviours like delinquency, violence and early-unwanted pregnancies.

Substance abuse constitutes a major threat to the survival and effective learning process of human societies. Lives are daily lost through addiction and activities of addicts. A significant number of deaths from accidents and violent crimes have been traced to the activities of persons under the influence of drugs (Folawiyo, 2008).

Mohammed (2018), in a report attributed the resurgence of youth violence in Jalingo metropolis, Taraba State to substance abuse and social vices and calls for urgent attention before it gets out of control of the political authorities as this is connected to various substances been abused by mostly Adolescents and Youths of various age grades. There is growing sub-culture among the Adolescents and Youths of forming groups based on age grade most of whom are school drop-outs. They form area/wards groups ('Yan Unguwa') solidarity networks. Basically, their actions are to conquer territory, compete among sister groups and cause insecurity leading to destruction of lives and property. They manifest the following attitudes of juvenile delinquencies: Drug abuse, gangsterism, attending night parties, gambling, sexual harassment, pick pockets and violence on the people usually during the evening and night times. Their mobility means is the tricycle. 
The boys who are mostly under 20 come from three major parts of the Jalingo metropolis: Mayo-Gwoi, Sabon-Layi and Bakin-kasuwan Jalingo. However, Mayo-Gwoi has been experiencing tension both day and night of possible vengeance attack from the Sabon-Layi boys. There are many groups now in Jalingo that pose security threat to the city and state at large. These groups are: (i) Wicked Banana (ii) Independent Marketers (iii) Black Scorpion and (iv) Friendship.

The study focuses on secondary school students who are mostly adolescents because they are the ones prone to experiment drugs. They are also the ones who pose a big challenge in Nigeria in terms of their needs and their views of the world. Consequently, during sports and other out of school activities, it is common to meet students taking alcohol or being suspended for having taken drugs. It is against this backdrop that the current study sets out to study the Perceived Impact of Substance Abuse on students' Academic Activities among Senior Secondary School Students in Jalingo Education Zone, Taraba State- Nigeria, with a view of suggesting intervention and counselling measures to salvage the drug abuse menace in our Secondary Schools.

\section{Statement of the Problem}

The scourge of substance abuse seems to be taking toll on students in secondary schools and other Educational Institutions of learning in Nigeria. Crimes and social vices are mostly associated with drug abuse. The impact is being felt by affected individuals, their families and the society. Substance abuse seems to be common among students in Jalingo Education Zone of Taraba State. Consequently, there seems to be common poor academic activities among the students. Could this be as a result of Substance abuse? What could the implication of this assumed trend be if not properly tackled?

\section{Purpose of the study}

The purpose of this study is to therefore, investigate the perceived impact of drug substance abuse on students' academic activities among senior secondary school in Jalingo Education zone, Taraba State, Nigeria.

\section{Research Question}

What is the perceived impact of drug substance abuse on students' academic activities among senior secondary school in Jalingo Education zone, Taraba State, Nigeria?

\section{Statement of Hypothesis}

One null hypothesis was tested for generalization of findings at 0.05 alpha level of significance:

There is no significant impact of drug substance abuse on students' academic activities among senior secondary school in Jalingo Education zone, Taraba State, Nigeria. 


\section{Methodology}

The research design adopted for this study is descriptive survey research design. The population of this study comprised of all the SSII students of 2019/2020 academic session in Jalingo Education Zone of Taraba State which has 47 senior secondary schools with a total enrolment of four thousand, five hundred and Ninety four students (TSPPMB, 2019/2020). This study is limited to SSII students because they are the most current set of students on ground and they form the most stable class suitable for the purpose of the study.

The sample size for this study is three hundred and sixty-eight. Multi-stage sampling was used to select the sample size for the study using the Taro Yamane's (1976) formula for determining sample size representing $23.3 \%$ of the entire population.

The main instrument for this study is questionnaire titled Perceived Impact of Substance Abuse on Students' Academic Activities Questionnaire tagged [PISASAAQ]. A pilot study was carried out on 40 male and female students at Government Day Secondary School Nukkai, a selected school not included among sampled schools for the main study. The pilot study yielded a Cronbach alpha coefficient index of 0.705. This shows that the instrument in reliable. Inferential statistics of Chi-square was used to test the hypothesis at 0.05 level of significance. Descriptive statistics of mean and standard deviation were used in answering the research questions using the SPSS package.

\section{DATA ANALYSIS, RESULTS AND DISCUSSIONS}

The data collected for the study are presented and analysed using mean and standard deviation to answer the research question.

\section{Research Question}

What is the perceived impact of drug substance abuse on students' academic activities among senior secondary school students in Jalingo Education Zone, Taraba State, Nigeria? 


\section{Table 1}

Means and standard deviations of rating scales on the impact of drug substance abuse on students' academic activities among senior secondary school students in Jalingo Education Zone, Taraba State Nigeria.

\begin{tabular}{|c|c|c|c|c|c|c|c|c|}
\hline $\mathbf{S} / \mathbf{N}$ & Statements & $\mathbf{S A}$ & $\mathbf{A}$ & $\mathbf{D}$ & SD & Mean & SD & Decision \\
\hline 1 & $\begin{array}{l}\text { Drugs abuse impact on student academic } \\
\text { activities }\end{array}$ & 141 & 111 & 51 & 63 & 2.90 & 1.10 & HI \\
\hline 2 & $\begin{array}{l}\text { There is no differences in terms of class } \\
\text { attendance between students that abuse } \\
\text { drug substances and those that do not }\end{array}$ & 70 & 82 & 87 & 127 & 2.26 & 1.13 & NI \\
\hline 3 & $\begin{array}{l}\text { Those that do well in group discussions } \\
\text { are drug substance abusers }\end{array}$ & 71 & 78 & 82 & 135 & 2.23 & 1.14 & NI \\
\hline 4 & $\begin{array}{l}\text { Student that are addicted to drug } \\
\text { substances have more confidence than } \\
\text { others }\end{array}$ & 83 & 95 & 77 & 111 & 2.41 & 1.14 & NI \\
\hline 5 & $\begin{array}{l}\text { Drugs abuse among student lead to } \\
\text { student academic failure }\end{array}$ & 186 & 112 & 31 & 37 & 3.22 & 0.98 & HI \\
\hline 6 & $\begin{array}{l}\text { Those that are addicted to Indian hemp } \\
\text { perform better during excursion }\end{array}$ & 70 & 78 & 97 & 121 & 2.74 & 1.11 & HI \\
\hline 7 & $\begin{array}{l}\text { Poor academic activities is generally } \\
\text { associated with drugs abuse }\end{array}$ & 141 & 125 & 55 & 45 & 2.99 & 1.01 & HI \\
\hline 8 & $\begin{array}{l}\text { Taking drugs can discourage students } \\
\text { from active participation in class }\end{array}$ & 179 & 127 & 30 & 30 & 3.24 & 0.92 & HI \\
\hline 9 & $\begin{array}{l}\text { For me, taking drugs do not affect my } \\
\text { academic activities }\end{array}$ & 46 & 51 & 82 & 187 & 3.12 & 1.07 & HI \\
\hline 10 & $\begin{array}{l}\text { It is when I take drug substances that I } \\
\text { study well }\end{array}$ & 30 & 44 & 102 & 190 & 3.24 & 0.96 & HI \\
\hline
\end{tabular}

Grand Mean =2.835

Source: Researcher's Field work, 2019

Results in table 1 shows that, all means of rating scales are above the bench mark of 2.50 except numbers 2,3 and 4 but the grand means shows 2.835 . These signify that drugs abuse has negative impact on student academic activities. 


\section{Hypothesis}

There is no significant impact of drug substance abuse on students' academic activities among senior secondary school students in Jalingo Education Zone, Taraba State.

\section{Table 2}

Chi-square Test of impact of drug substance abuse on students' academic activities among senior secondary school students in Jalingo Education Zone, Taraba State.

\begin{tabular}{llll}
\hline & Value & Df & $\begin{array}{l}\text { Asymp. Sig. } \\
\text { (2-sided) }\end{array}$ \\
\hline Pearson Chi-Square & $\begin{array}{l}3.641 \mathrm{E} \\
2^{\mathrm{a}}\end{array}$ & 156 & .000 \\
& 296.181 & 156 & .000 \\
Likelihood Ratio & 78.863 & 1 & .000 \\
Linear-by-Linear & & & \\
Association & 366 & & \\
N of Valid Cases & & \\
a. 165 cells (90.7\%) have expected count less than 5. The \\
minimum expected count is .01.
\end{tabular}

Table 2 presents chi-square at 156 degree of freedom $\left(x^{2}=3.641 \mathrm{E}, \mathrm{p}=.000\right)$; this result reveals that there is statistically significant impact of drug substance abuse on students' academic activities among senior secondary school students in Jalingo Education Zone, Taraba State. Thus, null hypothesis that says, there is no significant impact of drug substance abuse on students' academic activities among senior secondary school students in Jalingo Education Zone, Taraba State is hereby not retained, this further affirm that there is negative impact of substance abuse on students' academic activities among senior secondary school students in Jalingo Education Zone, Taraba State.

\section{Discussion of Findings}

The mean and standard deviation scores of the rating items of the impact of drug substance abuse on student academic activities among senior secondary school students in Jalingo Education Zone, Taraba State, Nigeria show that all the items have mean rating scale that shows the variable selected influences students' academic activities, including grand mean. This shows that drug substance abuse has influence on students' academic activities in Jalingo Education Zone of Taraba State, hence the grand mean and also the hypothesis tested at 156 degree of freedom $\left(x^{2}=3.641 \mathrm{E}, \mathrm{p}=.000\right)$ signifies that there is statistically significant impact of drug substance abuse on students' academic activities among senior secondary school students in Jalingo Education Zone, Taraba State. 
The finding of this study is in line with the findings of Jenny (2013) who explored the influence of Substance Abuse and Academic Activities such as excursion. The results indicated that substance abuse significantly influences academic activities of secondary school students especially in the field of excursion. Those abusing substance tend to misuse the avenue to either fail to attend or decline from the trip to join other peers outside.

The finding is in line with Sayo (2011) who conducted a study in Ashanti Region, Ghana on "Impact of Substance Abuse on Student's Class Attendance". From the findings of the study, it was realized that, the students who abuse substance tend to come late, leave school earlier than the closing hours and are found hanging around classes while class period is in progress. Meanwhile, the findings of Ekpenyong (2012), which investigated Drug Abuse in Nigerian schools divulged that substance abuse has negative impact on the students' academic activities particularly in the area of study habit. The common phenomena observed is, students who abuse substance tend to over read to a point of messing up entirely.

\section{Conclusion}

From the findings and discussion of the study, the following conclusions are made: the variable, Perceived Impact of Substance Abuse on Students' Academic Activities among Senior Secondary School Students, impacted on the students' academic activities in Jalingo Education Zone. It is found that respondents perceived that drug substance abuse has high impact on academic activities among Senior Secondary School Students in Taraba State Nigeria.

It is evident from the findings of the study that students' academic activities is related to or can be influenced by the abuse of substance, thus whenever there is an imbalance in the students to support his/her educational activities, there will be decline in learning academic activities.

\section{Recommendations Based on Findings}

Based on findings of the study, the following recommendations are made:

(1) Policy Makers of the States should develop inclusive policies that address the learning needs of all students by providing equitable access to learning opportunities, and differentiated strategies without discrimination on any grounds provided that substance abusers are realized among students.

(2) Policy Makers of the States should develop integrated policies using interdisciplinary and inter sectorial knowledge and expertise, encompassing education and training policies and related policy areas, such as health, environment, justice, standing laws against drugs abuse and culture. 
To develop good academic activities, State Government should consider:

(a) Strengthening or creating inter-ministerial forums to articulate across sectors the roles of learning and education in the lifelong learning spectrum, as well as its contributions to the development of societies;

(b) Involving all relevant stakeholders, including parliamentarians, public authorities, academia, civil society organizations, and the private sector as partners in policy development against drug abuse;

(c) Providing suitable structures and mechanisms for the development of education policies, whilst ensuring that the policies developed are flexible enough to adapt to future needs, issues and challenges particularly to those that abuse drugs.

\section{Implications for Counselling:}

To nurture a favorable policy environment, State Government should consider:

1. Educational counselling need to take place within an environment of learning ensuring presence of qualified counsellors to implement relative Guidance Programmes.

2. Well-equipped Counselling unit and or clinic should be established in every school.

3. Community/ Group counselling should be encouraged.

4. Every secondary school should have a counsellor.

5. Raising awareness, through legislation, institutions and sustained political commitment, of substance abuse and education as an essential component of the right to education and a key pillar in the education system.

6. Taking measures to provide information, motivate learners and guide them towards relevant learning opportunities and demotivate them towards maladaptive behavior.

7. Assist the students to create new, more flexible arrangement that will aid persistence, through prioritization of daily activities, especially assignments, time spent on work, hobbies, family or friends and make decision how to manage the time well.

8. Help students to adopt behaviours that are positive through the development of attitudes that build up self-confidence.

9. Assist students to see clearly the aims, goals and ideas of learning situation and be able to know what has to be done, when to do it and how to do it. It follows up with the client to monitor the progress or attainability of the goals set.

10. Assist students in making career and occupational decision with methods of measuring knowledge and skills like inventories, questionnaire, and tests to verify or refute any claim.

11. Assist in the promotion of advocacy as a tool for raising the profile of students and lifelong learning.

12. Keep records and prepare reports related to the needs of students, which will later form baseline data for further studies. 


\section{References}

Coleman E. (2010). Drug Use and Abuse among Students in Tertiary Institutions. The Case of Federal University of Technology Minna. Journal of Research in National Development Vol.8 No 1, June, 2010.

Ekpeyong (2012). Drug Abuse in Nigerian Schools: A Study of Selected Secondary Institutions in Bayelsa State, South-South, Nigeria. International Journal of Scientific Research in Education, vol 5(3), 260-268.

Folawiyo, A.A. (2008). Overview of the research process. Research process in Education and Social Sciences. A.A. Folawiyo and M.G. Folawiyo. Eds. Lagos: Goldy O. Publishing Co.1-15.

Idoko, Muyiwa and Aghoha (2015), The Effects of Alcohol Consumption on the academic Performance of Undergraduate Students: Psychology and Behavioural Sciences 2015: vol4, No.4, pp. 147-153.

Jenny, (2013). The application of a person-oriented approach: Types and clusters. In L. R. Bergman, R. Cairns, L.-G. Nilsson, \& L. Nystedt (Eds.), Developmental science and the holistic approach (pp. 137-154). Mahwah, NJ: Erlbaum.

Mohammed, I. (2018). The Resurgence of Youth Violence in Jalingo: Taraba Facts, 22, February 2018

National Drug Law Enforcement Agency (2013). Cause of Drug Abuse in School Adolescent in Edo State, Nigeria Review of African Political Affairs ND-EA Data Collection Unit, Lagos

Okogun (2016). Literacy in Everyday Life: Results From the2003 National Assessment of Adult Literacy (NCES 2007-480). U.S. Department of Education. Washington, DC: National Center for Education Statistics.

Omoruyi (2014).Differential affective responses in those with aggressive versus nonaggressive antisocial behaviors. Personality and Individual Differences, 43, 14811492.

Sayo (2011). A person approach in research on adolescence: Some methodological challenges. Journal of Adolescent Research, 16, 28-53. 